\title{
Williams Trait
}

\author{
HUMAN KININOGEN DEFICIENCY WITH DIMINISHED \\ LEVELS OF PLASMINOGEN PROACTIVATOR AND \\ PREKALLIKREIN ASSOCIATED WITH ABNORMALITIES OF THE \\ HAGEMAN FACTOR-DEPENDENT PATHWAYS
}

\author{
Robert W. Colman, Andranik Bagdasarian, Richard C. Talamo, \\ Cheryl F. Scott, Marya Seavey, Jorge A. Guimaraes, Jack V. Pierce, \\ and Allen P. Kaplan with the technical assistance of LisSa Weinstein \\ From the Coagulation Unit of the Hematology-Oncology Section, Department \\ of Medicine, University of Pennsylvania, Philadelphia, Pennsylvania 19104; \\ The Department of Pediatrics, Johns Hopkins Hospital, Baltimore, Maryland \\ 21205; The Section on Physiological Chemistry, Hypotension-Endocrine \\ Branch, National Heart and Lung Institute; and The Allergic Diseases Section, \\ Laboratory of Clinical Investigation, National Institute of Allergy and Infectious \\ Diseases, National Institutes of Health, Bethesda, Maryland 20014
}

\begin{abstract}
A B STRACT An asymptomatic woman (Ms. Williams) was found to have a severe abnormality in the surface-activated intrinsic coagulation, fibrinolytic, and kinin-generating pathways. Assays for known coagulation factors were normal while Fletcher factor (prekallikrein) was $45 \%$, insufficient to account for the observed markedly prolonged partial thromboplastin time. Plasminogen proactivator was present at $20 \%$ of normal levels and addition of highly purified plasminogen proactivator containing $10 \%$ plasminogen activator partially corrected the coagulation and fibrinolytic abnormalities but not the kinin-generating defect. This effect was due to its plasminogen activator content. In addition, Williams trait plasma failed to convert prekallikrein to kallikrein or release kinin upon incubation with kaolin. Kininogen antigen was undetectable. When normal plasma was fractionated to identify the factor that corrects all the abnormalities in Williams trait plasma, the Williams factor was identified as a form of kinino-
\end{abstract}

This work was presented at the International Conference of the Biology of the Kallikrein-Kinin System in Health and Disease, Reston, Va., 22 October 1974. and has appeared in abstract form (Fed. Proc. 1975. 34: 859).

Address reprint requests to Dr. A. Kaplan at the National Institutes of Health, Bethesda, Md.

Received for publication 27 Ma! 1975 and in revised form 18 August 1975. gen by its behavior on ion exchange chromatography, gel filtration, disc gel electrophoresis, and elution from an anti-low molecular weight kininogen immunoadsorbent. High molecular weight kininogen, as well as a subfraction of low molecular weight kininogen, possessed this corrective activity while the bulk of low molecular weight kininogen functioned only as a kallikrein substrate. Kininogen therefore is a critical factor required for the functioning of Hageman factor-dependent coagulation and fibrinolysis and for the activation of prekallikrein.

\section{INTRODUCTION}

Hageman factor (Factor XII) is known to initiate the plasma coagulation (1), kinin-forming (2), and fibrinolytic pathways of human plasma $(3,4)$ by activating the precursor proteins, plasma thromboplastin antecedent (Factor XI) (PTA) ${ }^{1}$ (1), prekallikrein (Fletcher factor) (5), and plasminogen proactivator (6), respectively, to their respective active enzymes. Although

${ }^{1}$ Abbreviations used in this paper: $\mathrm{CM}$, carboxymethyl; DFP, diisopropylfluorophosphate; PTA, plasma thromboplastin antecedent; PTT, partial thromboplastin time; QAE, quaternary aminoethyl; SDS, sodium dodecyl sulfate; SP. sulfopropyl; TAMe, tosyl L-arginine methyl ester. 
patients with deficiency of Factor XII (Hageman trait) have no symptoms $(7)$, in vitro testing of their plasmas reveals profound defects in surface-activated coagulation, kinin formation, and fibrinolysis. In contrast, Factor XI deficiency in man results in a mild bleeding tendency (8) with a defect in the rate of thrombin formation but no abnormality in kallikrein or plasmin formation. Individuals lacking prekallikrein (9) resemble those with Factor XII deficiency and display, in addition to the expected absence of kinin formation, a diminished rate of surface-activated coagulation and fibrinolysis $(10,11)$. These latter abnormalities are attributed to a feedback requirement in which kallikrein activates Factor XII to an enzyme that can then act upon each substrate (11-13).

This report describes an unusual patient, Ms. Williams, with profound abnormalities of the Hageman factor-dependent pathways, who has diminished levels of prekallikrein and plasminogen proactivator and undetectable kininogen. High molecular weight kininogen and a subfraction of low molecular weight kininogen are identified as the corrective factors.

\section{METHODS}

Bradykinin triacetate (Sandoz Ltd., Basel, Switzerland) was used as the standard for native bradykinin. Hexadimethrine bromide (Aldrich Chemical Co., Inc., Milwaukee, $\mathrm{W}$ is.) ; tosyl L-arginine methyl ester (TAMe), and agarose (Sigma Chemical Co., Inc., St. Louis, Mo.) ; enzodiffusion fibrin plates, polystyrene dishes for immunodiffusion, and streptokinase (Hyland Div., Travenol Laboratories, Inc., Costa Mesa, Calif.) ; quaternary aminoethyl (QAE) Sephadex A-25, sulphopropyl (SP) Sephadex, carboxymethyl (CM) Sephadex, Sephadex G 150, and G 200 (Pharmacia Fine Chemicals, Inc., Piscataway, N. J.) ; DEAE 52 cellulose (Whatman Chemicals, Div. W. \& R. Balston, Maidstone, Kent, England) ; Bio-Gel A 0.5 m (Bio-Rad Laboratories, Richmond, Calif.); hemostatic phosphatide (cephalin) (ICN Nutritional Biochemicals Div., International Chemical \& Nuclear Corp., Cleveland, Ohio); and rabbit antisera against $\alpha_{2}$-macroglobulin, Cī-inactivator, $\alpha_{1}$-antitrypsin, $\alpha_{1}$-antichymotrypsin, inter- $\alpha$-trypsin inhibitor, antithrombin III, and quantitative tripartigen immunodiffusion plates for IgG, IgA, and IgM (Behringwerke AG, Marburg-Lahn, West Germany) were obtained as indicated.

Hageman factor-deficient plasma and PTA-deficient plasma containing $0.38 \%$ citrate were fresh-frozen plasma of severely deficient patients collected by ourselves or by Sera-Tec Biologicals, New Brunswick, N. J. Fletcher factor-deficient plasma was a gift from Dr. C. Abildgaard (University of California, Davis, Calif.). Anti-human plasma kallikrein was prepared in rabbits and adsorbed with Fletcher factor-deficient plasma as described previously (14). Sheep antibody to human low molecular weight kininogen was prepared as previously reported $(15,16)$.

Preparation of plasma proteins. To obtain normal human plasma for use in assays, 9 vol of blood from healthy donors was drawn directly into plastic tubes containing 1 vol of $3.8 \%$ citrate. The plasma was centrifuged at $250 \mathrm{~g}$ at $4^{\circ} \mathrm{C}$ to remove the cells. $1-\mathrm{ml}$ aliquots of plasma were stored at $-70^{\circ} \mathrm{C}$ and used immediately after thawing. Any residual p'asma was discarded. Plasma from Ms. Williams was collected and handled identically.

Plasma utilized for the isolation of Hageman factor fragments, prekallikrein, plasminogen proactivator, Factor XI (pre-PTA), plasminogen, and kininogen was collected in $0.38 \%$ sodium citrate. $3.6 \mathrm{mg}$ of hexadimethrine bromide in $0.1 \mathrm{ml}$ of $0.15 \mathrm{M}$ saline was added for each $10 \mathrm{ml}$ of blood drawn. The tubes were centrifuged at $900 \mathrm{~g}$ for 20 $\min$ at $4^{\circ} \mathrm{C}$ and the plasma was separated with plastic pipettes. Plastic columns and test tubes were utilized throughout all chromatographic procedures to minimize contact activation of Hageman factor. Samples were concentrated by ultrafiltration through a UM-10 membrane (Amicon Corp., Lexington, Mass.). Gel filtration on Sephadex G 150 (6), alkaline disc gel electrophoresis (5), and sodium dodecyl sulfate (SDS) gel electrophoresis (17) were performed as previously described. Protein was approximated by absorbance at $280 \mathrm{~nm}$, with $A_{280}{ }^{1 \%}$ assumed to equal 10 , or was determined by micro-Kjeldahl analysis.

Acticated Hageman factor. For experiments utilizing the radioimmunoassay for bradykinin, the large activator and prealbumin fragments derived from Hageman factor were prepared by sequential fractionation of plasma with ethanol, isoelectric precipitation, ion exchange chromatography utilizing DEAE cellulose and CM Sephadex, and gel filtration on Sephadex G 150, as described by Bagdasarian et al. (18).

Hageman factor prealbumin fragments utilized in fibrinolytic assays and in the bioassay of prekallikrein were purified by chromatography of plasma on QAE Sephadex twice, Sephadex G 100, SP Sephadex, and elution from alkaline disc gels after electrophoresis, as previously reported by Kaplan et al. (19). After dialysis, the fragments were concentrated and routinely used at $25 \mu \mathrm{g} / \mathrm{ml}$. When assessed functionally, $5 \mu \mathrm{l}$ of Hageman factor fragment generated $100 \mathrm{ng}$ of bradykinin after incubation with $0.2 \mathrm{ml}$ fresh plasma for $2 \mathrm{~min}$ at $37^{\circ} \mathrm{C}$. There was no detectable contamination with any of the Hageman factor substrates, plasminogen, plasmin, or kininogen.

Hageman factor substrates. Pre-PTA, prekallikrein, and plasminogen proactivator were isolated from the effluent obtained after passage of $500 \mathrm{ml}$ of plasma over a $10 \times 100$ $\mathrm{cm}$ column of QAE Sephadex at $\mathrm{pH}$ 8.3. The proenzyme mixture was concentrated to $100 \mathrm{ml}$, the $\mathrm{pH}$ brought to $\mathrm{pH} 6.0$ with $1 \mathrm{~N} \mathrm{HCl}$, and each proenzyme isolated by sequential chromatography once on SP Sephadex, and twice on Sephadex G 150, as described previously (11).

Plasminogen. Plasminogen was prepared by affinity chromatography by a modification of the procedure of Deutsch and Mertz (20). $100 \mathrm{ml}$ of plasma was passed over a $3 \times 25 \mathrm{~cm}$ column of lysine Sepharose $4 \mathrm{~B}$ and the plasminogen eluted with $0.2 \mathrm{M}$ epsilon-amino caproic acid. The plasminogen was concentrated, dialyzed overnight at $4^{\circ} \mathrm{C}$ against $0.003 \mathrm{M}$ phosphate buffer containing $0.15 \mathrm{M} \mathrm{NaCl}$, and further fractionated by Sephadex G 100 gel filtration. The plasminogen peak was pooled, concentrated, and adjusted to $200 \mu \mathrm{g} / \mathrm{ml}$ for routine use. The preparation contained less than $1 \%$ plasmin and gave a single band at mol wt 90,000 upon SDS gel electrophoresis after reduction and alkylation.

Kininogen. Highly purified kininogens were prepared by the method of Pierce and Guimaraes (21, 22). 10 liters of human plasma, diluted to 50 liters with distilled water and made to $0.01 \%$ hexadimethrine bromide, were stirred with $500 \mathrm{~g}$ of DEAE-cellulose (DE-23) at $\mathrm{pH} 6.0$ and $25^{\circ} \mathrm{C}$. The filtered and washed adsorbent was eluted with $0.4 \mathrm{M}$ Tris- $\mathrm{HCl}, \mathrm{pH}$ 6.0. The eluate, adjusted to $\mathrm{pH}$ 7.1, was 
passed over an anti-low molecular weight kininogen immunoadsorbent, followed by several bed volumes of phosphate-buffered saline, $\mathrm{pH}$ 7.0. The kininogen was eluted with $8 \mathrm{M}$ guanidine, dialyzed, and chromatographed on DEAE-cellulose. Four main peaks of kininogen activity: coincident with the $A_{2 s 0}$ peaks and named $\mathrm{B} 1, \mathrm{~B} 2, \mathrm{~B} 3$, and $\mathrm{B} 4$, were eluted from the column by a linear gradient of $0.05-$ $0.30 \mathrm{M}$ phosphate, $\mathrm{pH}$ 6.0. Gel filtration of the $\mathrm{B}$ peaks on Bio-Gel A $0.5 \mathrm{~m}$ gave nominal $\mathrm{mol}$ wt of $80,000,150,000$, and 225,000 , called $\alpha, \beta$, and $\gamma$, respectively (22). B4- $\gamma$ kininogen yielded a single major band upon alkaline disc gel electrophoresis, and immunization of a sheep with 1.0 $\mathrm{mg}$ of this material yielded a monospecific antikininogen.

The antikininogen immunoadsorbent was prepared as follows: sheep anti-low molecular weight kininogen (15), shown to be monospecific by immunoelectrophoresis against normal serum, was passed over a column of low molecular kininogen coupled to agarose by the cyanogen bromide procedure (23). The antikininogen was eluted with $8 \mathrm{M}$ guanidine and dialyzed against phosphate-buffered saine, and the purified antikininogen globulins coupled to agarose by the cyanogen bromide procedure. In this fashion a highcapacity column that specifically binds kininogen was prepared. Since antibody to low molecular weight kininogen cross-reacts with high molecular weight kininogen (15). this column was used to isolate both forms. A column of $450 \mathrm{ml}$ bed volume removes all the kininogen from 1.8 liters of plasma. This procedure is shown diagrammatically at the left of Table I. When normal plasma was fractionated to identify the Williams factor as it was eluted from each column, the procedure shown on the right of Table I was utilized.

\section{Assay procedures}

Determination of plasma proteolytic inhibitors. Quantitation of plasma proteins by radial immunodiffusion was performed by a modification of the procedure of Mancini et al. (24). Diffusion plates were prepared with 6 vol of $1.5 \%$ agarose and 1 vol of absorbed antisera and 1 vol of barbital buffer, $\mathrm{pH}$ 7.6, containing merthiolate to give a final concentration of $0.01 \% .3 .6 \mathrm{ml}$ of the mixture was placed on each diffusion dish and left to stand overnight in a moist chamber at $4^{\circ} \mathrm{C}$. Wells of $2.25 \mathrm{~mm}$ diameter were then bored in the gel. Varying volumes from 5 to $15 \mu 1$ were placed in the wells and the reaction was recorded at $18 \mathrm{~h}$ and $48 \mathrm{~h}$. No difference in the diameter of the precipitin rings was found after $18 \mathrm{~h}$. Total plasma inhibitory activity against plasma kallikrein (25) was measured by the method of Gigli et al. (26).

Coagulation assays. The partial thromboplastin time (PTT) was measured by the method of Proctor and Rappoport (27). Factors VIII, IX, XI, XII, and Fletcher factor were determined by a modification of the PTT with congenitally deficient plasmas. Factor II was assayed by the method of Owren and Aas (28), Factor V by the method of Lewis and Ware (29), Factor VII by the method of Pechet (30), and Factor X by the procedure of Bachmann (31). Fibrinogen was measured according to Clauss (32) and fibrinogen degradation products by the procedure of Garvey and Block (33).

Fibrinolvtic assays. Plasminogen levels in plasma were determined by the method of Alkjaersig et al. (34).

Plasmin was assayed with Hyland fibrin plates, as previously described (6). A standard curve relating ring diameter to plasmin concentration was obtained by activating $0.2 \mathrm{ml}$ of a reference preparation of purified plasminogen containing $250 \mu \mathrm{g} / \mathrm{ml}$ with $140 \mathrm{U}$ of streptokinase for 30 min at $37^{\circ} \mathrm{C}$; a linear plot relating $\log$ concentration plasmin to ring diameter was obtained between 3 and $250 \mu \mathrm{g}$ plas$\mathrm{min} / \mathrm{ml}$.

Plasminogen was assayed by incubating $0.2 \mathrm{ml}$ of plasminogen source with $140 \mathrm{U}$ streptokinase for $30 \mathrm{~min}$ at $37^{\circ} \mathrm{C}$, and determining the plasmin generated by the fibrin plate assay or by the caseinolytic assay of Alkjaersig et al. (34).

Plasminogen activator was assayed by incubating $20 \mu \mathrm{l}$ of plasminogen activator source with $20 \mu \mathrm{l}$ plasminogen $(200 \mu \mathrm{g} / \mathrm{ml})$ for $1 \mathrm{~h}$ at $37^{\circ} \mathrm{C}$, and determining the plasmin generated by fibrin plate.

Plasminogen proactivator was assayed by incubation of 10 $\mu \mathrm{l}$ plasminogen proactivator source with $10 \mu 1$ Hageman factor fragments $(25 \mu \mathrm{g} / \mathrm{ml})$ for $10 \mathrm{~min}$ at $37^{\circ} \mathrm{C} .20 \mu 1$ of plasminogen $(200 \mu \mathrm{g} / \mathrm{ml})$ was added, the mixture was incubated for $1 \mathrm{~h}$ at $37^{\circ} \mathrm{C}$, and the plasmin generated was determined by the fibrin plate assay.

Kaolin-activated fibrinolytic activity in diluted plasma was assessed according to Weiss et al. (11).

Assays of kinin-forming enzymes and substrates. Kallikrein activity was determined either by its arginine esterase activity or by its proteolytic activity. Esterase activity was determined with TAMe as the substrate by a modification of the method of Siegelman et al. (35), which has been described in detail (36). The proteolytic activity of kallikrein was measured by its ability to release bradykinin from plasma containing $3 \mathrm{mM}$ o-phenanthroline or from

TABLE I

Isolation of Human Kininogens and Proteins Correcting Williams Trait Plasma

\begin{tabular}{l}
\hline Isolation of human kininogens \\
\hline 10 liters human plasma
\end{tabular}


heat-inactivated plasma (5). Routinely, $25 \mu \mathrm{l}$ of kallikrein source (14), containing approximately $1 \mu \mathrm{mol}$ TAMe esterase $/ \mathrm{ml}$, was incubated with $0.2 \mathrm{ml}$ substrate for $2 \mathrm{~min}$ at $37^{\circ} \mathrm{C}$ and the bradykinin was quantitated by bioassay, as previously described (5).

Prekallikrein was determined by incubation of $25 \mu \mathrm{l}$ of proenzyme source with $25 \mu \mathrm{l}$ Hageman factor fragments $(25 \mu \mathrm{g} / \mathrm{ml})$ for $5 \mathrm{~min}$ at $37^{\circ} \mathrm{C}$ and determination of the kallikrein generated. Immunoassay for prekallikrein was performed by the method of Bagdasarian et al. (14).

Kininogen was assayed functionally from column fractions by incubation of $0.5 \mathrm{ml}$ of each fraction with $0.1 \mathrm{ml}$ trypsin $\left(1 \mathrm{mg} / \mathrm{ml}\right.$ ) for $30 \mathrm{~min}$ at $37^{\circ} \mathrm{C}$, inactivation of trypsin by further incubation with $0.1 \mathrm{ml}$ soybean trypsin inhibitor (1 $\mathrm{mg} / \mathrm{ml}$ ) for $30 \mathrm{~min}$ at $37^{\circ} \mathrm{C}$, and determination of the bradykinin generated by bioassay. Kininogen was located antigenically by electroimmunodiffusion (counterimmunoelectrophoresis), performed as described by Schreiber et al. (37). The precipitin lines were graded by inspection on a $0-4+$ scale. The ability of highly purified kininogen to generate bradykinin upon incubation with plasma kallikrein was determined by incubation of $100 \mu 1$ kininogen $(150 \mu \mathrm{g} / \mathrm{ml})$ with $10 \mu \mathrm{l}$ kallikrein $(50 \mu \mathrm{g} / \mathrm{ml})$ for $10 \mathrm{~min}$ at $37^{\circ} \mathrm{C}$ and determination of the bradykinin generated.

Bradykinin was routinely determined by bioassay (5), and in selected experiments the results were confirmed by the radioimmunoassay technique described by Talamo et al. (38).

Assay of Williams factor. Chromatographic fractions were assayed by testing the ability of these fractions to correct the coagulation and fibrinolytic defects of Williams trait plasma. The coagulation assay was performed by adding $50 \mu \mathrm{l}$ of each fraction to $50 \mu \mathrm{l}$ of Williams trait plasma and performing a PTT at room temperature. To quantitate the ability of concentrates of these column fractions to correct the coagulation defect in Williams trait plasma, we used a method similar to that employed to determine Fletcher factor. $100-\mu 1$ dilutions of the concentrate were added to $100 \mu \mathrm{l}$ of Williams trait plasma and a PTT (27) was performed at $37^{\circ} \mathrm{C}$. Normal plasma was then serially diluted and mixed with equal volumes of Williams trait plasma, the PTT was determined, and a standard curve relating log clotting time to $\log$ dilution was plotted. A linear relationship was observed. The PTT obtained with the column fractions was then related to the percentage of normal plasma by interpolation on the standard curve. The fibrinolytic assay was performed as previously described for Fletcher factor deficiency (11); however, in this case, Williams trait plasma was used as the substrate. The ability of concentrates to correct the abnormality in prekallikrein activation was tested by adding $50 \mu \mathrm{l}$ of the fraction to $50 \mu \mathrm{l}$ of Williams trait plasma and measuring kaolin-activated arginine esterase activity (36).

\section{RESULTS}

Case report. Ms. Williams is a 64-yr-old black woman referred to the Hospital of the University of Pennsylvania because of a prolonged PTT obtained as part of a routine preoperative evaluation of her hemostatic mechanism. Table II shows the results of an evaluation of her coagulation and fibrinolytic pathways. The PTT was markedly prolonged. However, all of the recognized coagulation Factors I-XII were within normal limits. In addition, disseminated intravascular coag-
TABLE II

Coagulation, Fibrinolytic, and Inhibitor Studies of Williams Plasma

\begin{tabular}{lcc}
\hline & Williams & Normal $\pm 1 \mathrm{SD}$ \\
\hline PTT, $s$ & 171 & $30 \pm 3.5$ \\
Prothrombin time & 13.2 & $12 \pm 1.0$ \\
Platelet count, $\mu l^{-1}$ & 256,000 & $250,000 \pm 50,000$ \\
Factor I (fibrinogen), $m g / m l$ & 370 & $290 \pm 60$ \\
Factor II (prothrombin), $\% / c$ & 200 & $100 \pm 20$ \\
Factor V, $\%$ & 110 & $100 \pm 20$ \\
Factor VII, $\%$ & 88 & $100 \pm 20$ \\
Factor VIII, $\%$ & 200 & 50 to $200^{*}$ \\
Factor IX, $\%$ & 93 & $100 \pm 12$ \\
Factor X, $\%$ & $100 \pm 20$ \\
Factor XI, $\%$ & 90 & $100 \pm 20$ \\
Factor XII, $\%$ & 95 & $100 \pm 20$ \\
Plasminogen, casein $U / m l$ & 6.0 & $5.5 \pm 1.5$ \\
Thrombin time, $s$ & 22 & $20 \pm 1.5$ \\
Fibrinogen degradation & & \\
$\quad$ products, $\mu g / m l$ & 2.5 & $2.5 \pm 1.2$ \\
\hline
\end{tabular}

$* 95 \%$ range.

ulation with secondary fibrinolysis was not present, as indicated by normal plasma fibrinogen level, platelet count, thrombin time, and fibrin degradation products.

The major plasma proteolytic enzyme inhibitors, $\alpha_{1-}$ antitrypsin, $\alpha_{2}$-macroglobulin, antithrombin III, the inhibitor of the activated first component of complement, $\alpha_{1}$-antichymotrypsin, and inter- $\alpha$-trypsin inhibitor were present in normal concentrations, as determined by radial immunodiffusion against monospecific antisera. Further studies revealed normal serum proteins, both qualitatively and quantitatively upon serum electrophoresis and immunoelectrophoresis, and there were normal levels of the major immunoglobulin classes (IgG 10.2 $\mathrm{mg} / \mathrm{ml}, \operatorname{IgM} 1.1 \mathrm{mg} / \mathrm{ml}$, and $\operatorname{IgA} 0.86 \mathrm{mg} / \mathrm{ml}$ ). Liver function tests, including serum alkaline phosphatase, glutamic-oxaloacetic transaminase, direct and indirect bilirubin, total protein, and albumin, were normal. The patient had mild obesity, varicose veins, a hiatus hernia, and cholelithiasis, but no symptoms suggestive of a hemorrhagic or thrombotic disorder. A cholecystectomy was performed without any unusual bleeding, and transfusion of plasma or coagulation factor concentrates were not necessary. Members of this family are not available for study at the present time.

Coagulation defect. The results of further investigation of the coagulation defect of Williams trait plasma are shown in Table III. The abnormal PTT was fully corrected by addition of 25 parts of normal plasma, Hageman factor-deficient plasma, or Fletcher factor (prekallikrein)-deficient plasma to 75 parts of Williams trait plasma, indicating that the factor(s) that corrects the Williams trait coagulation defect is present in these 
TABLE III

Correction of the Coagulation Defect in II illiams.

Trait by Other Plasmas

\begin{tabular}{|c|c|c|c|c|}
\hline $\begin{array}{l}\text { Williams } \\
\text { trait }\end{array}$ & $\begin{array}{l}\text { Fletcher } \\
\text { trait }\end{array}$ & $\begin{array}{c}\text { Hageman } \\
\text { trait }\end{array}$ & Nirmal & PTT \\
\hline \multicolumn{4}{|c|}{ ul plasma utilized in PTT assay } & $s$ \\
\hline $100^{*}$ & - & - & 0 & 171.0 \\
\hline- & - & - & 100 & 37.0 \\
\hline - & 100 & - & - & 110.0 \\
\hline- & - & 100 & - & 302.0 \\
\hline 75 & - & - & 25 & 38.2 \\
\hline 75 & 25 & - & - & 33.6 \\
\hline 75 & - & 25 & - & 3.5 .5 \\
\hline
\end{tabular}

plasmas. The coagulation abnormality was further distinguished from that observed with Fletcher trait deficiency in that incubation with kaolin for $30 \mathrm{~min}$ did not shorten the PTT. Direct measurement of prekallikrein by a coagulant assay with Fletcher trait plasma as a substrate revealed $43 \%$ prekallikrein. This was confirmed by a radial immunodiffusion assay that demonstrated that Williams trait plasma had $45 \%$ prekallikrein antigen.

Fibrinolytic defect. Williams trait plasma also revealed a profound abnormality in the Hageman factordependent fibrinolytic pathway. Although normal plasma, Williams trait plasma, and Fletcher trait plasma have approximately the same euglobulin lysis time in the absence of kaolin. the addition of kaolin

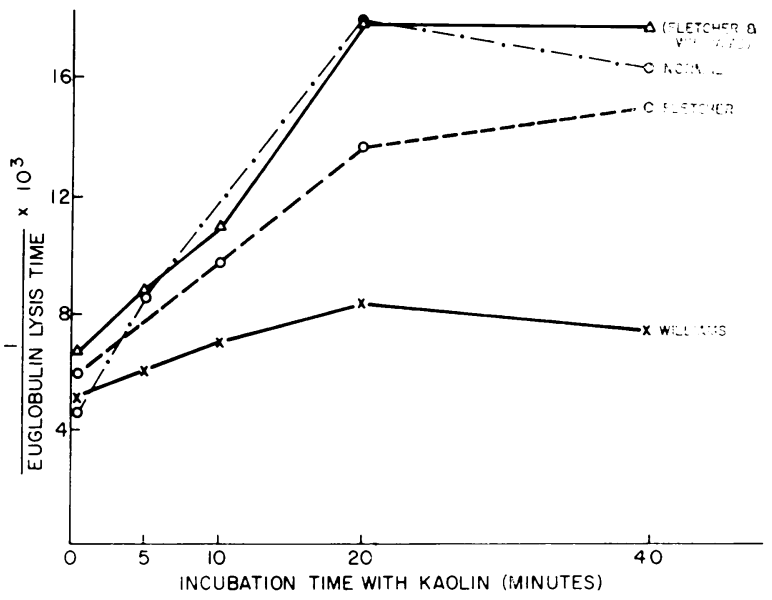

FIgUre 1 Comparison of the kaolin-activated euglobulin lysis time of Williams trait plasma, normal plasma, and Fletcher trait plasma. $0.5 \mathrm{ml}$ of each plasma or an equal mixture of Williams and Fletcher trait plasmas were added to 4.25 $\mathrm{ml}$ of sodium acetate buffer, $\mathrm{pH} 4.8 .0 .25 \mathrm{ml}$ of kaolin (8 $\mathrm{mg} / \mathrm{ml}$ ) was added, the mixture was incubated at $37^{\circ} \mathrm{C}$, and aliquots of $0.2 \mathrm{ml}$ were removed at intervals. The plasmin generated was determined as the euglobulin lysis time.



Figure 2 Comparison of the kaolin-activated arginine esterase activity of Williams trait plasma, normal plasma, and Fletcher trait plasma. $1 \mathrm{ml}$ of each plasma was mixed with $1 \mathrm{ml} 0.1 \mathrm{M}$ sodium phosphate buffer, $\mathrm{pH} 7.6$, containing $0.15 \mathrm{M} \mathrm{NaCl}$. An equal volume of a $10 \mathrm{mg} / \mathrm{ml}$ solution of kaolin was added, the mixture was incubated at $37^{\circ} \mathrm{C}$, and at intervals $0.2 \mathrm{ml}$ was removed, added to $0.05 \mathrm{M} \mathrm{TAMe}$, and assayed for methanol release. In a separate experiment, $1 \mathrm{ml}$ of Williams and Fletcher trait plasmas were mixed and assayed in the same fashion.

markedly increases the fibrinolytic potential of normal plasma, as assessed by the reciprocal of the euglobulin lysis time shown in Fig. 1. A diminished rate of enhancement of fibrinolysis by kaolin in Fletcher trait plasma is demonstrated, as previously reported (11). In contrast, incubation with kaolin yielded virtually no enhancement of the fibrinolytic activity of Williams trait plasma. A mixture of Williams and Fletcher trait plasmas, however, possessed a normal kaolin-activatable euglobulin lysis time.

Defect in prekallikrcin activation. The arginine esterase activity generated by kaolin activation of Williams trait plasma was compared to that of normal plasma and Fletcher trait plasma, as shown in Fig. 2. Williams trait plasma generated extremely low levels of arginine esterase activity within the first $10 \mathrm{~min}$ of exposure to kaolin and in this respect appeared similar to Fletcher trait plasma. Thus, in the presence of a normal quantity of Hageman factor, activation of its prekallikrein was not observed. Nevertheless, kaolin activation of a mixture of equal volumes of Fletcher trait plasma. which contains no prekallikrein, and Williams trait plasma yielded about $40 \%$ of the normal 1-min arginine esterase activity, consistent with the prekallikrein content of $43-45 \%$ of normal in Williams trait plasma.

Absence of bradykinin formation secondary to kininogen deficiency. Kaolin treatment of Williams trait 
TABLE IV

Bradykinin Generation in Williams Plasma

\begin{tabular}{|c|c|c|c|}
\hline & Kaolin & $\begin{array}{l}\text { Hageman } \\
\text { factor } \\
\text { fragments }\end{array}$ & Kallikrein \\
\hline & \multicolumn{3}{|c|}{$n g / m l$} \\
\hline Williams plasma & 0 & 0 & 0 \\
\hline Normal plasma & 250 & 225 & 150 \\
\hline Williams plasma & & & \\
\hline + kininogen & 100 & 100 & 150 \\
\hline
\end{tabular}

$0.2 \mathrm{ml}$ plasma was incubated with either $1 \mathrm{mg}$ kaolin, $10 \mu \mathrm{g}$ Hageman factor fragments, or $10 \mu \mathrm{g}$ kallikrein for $2 \mathrm{~min}$, and the bradykinin generated was determined. Kininogen was added to yield a final concentration of $0.5 \mathrm{mg} / \mathrm{ml}$.

plasma generated no bradykinin, consistent with its inability to activate prekallikrein (Table IV). However, the abnormality in bradykinin formation was not due solely to an inability to activate prekallikrein, since incubation of Williams trait plasma with activated Hageman factor fragments or kallikrein did not generate any bradykinin, although each of these enzymes released bradykinin from normal plasma. These observations suggested that Williams trait plasma either lacks functional kininogen or contains a potent kallikrein inactivator. When purified kallikrein was incubated with normal plasma or Williams trait plasma for $1 \mathrm{~min}$ and residual arginine esterase activity was determined, no difference was detected (Williams $59.5 \%$, normal $56 \%$ inhibition). When Williams trait plasma was reconstituted with a kininogen-containing fraction obtained from the QAE Sephadex chromatography of normal plasma (see below), incubation with kallikrein yielded the same quantity of bradykinin as did normal plasma (Table IV).

Incubation of the reconstituted Williams trait plasma with kaolin or Hageman factor fragments generated $40 \%$ of the bradykinin observed in normal plasma, consistent with the prekallikrein content of Williams trait plasma. Thus reconstitution with kininogen not only provided a kallikrein substrate, but also appeared to correct the abnormality in prekallikrein activation. The functional defect in bradykinin generation was confirmed by a radioimmunoassay for bradykinin. There was no detectable bradykinin generation when Williams trait plasma was activated with kaolin, large activator, Hageman factor fragments, or kallikrein.

We next estimated the level of kininogen protein in Williams trait plasma by immunodiffusion (39) with monospecific antibody to human low-molecular weight kininogen. As shown in Fig. 3, a precipitin line is evident when this antiserum is reacted against normal plasma or a 1:4 dilution of normal plasma, while no precipitin line was detected in Williams trait plasma. A quantitative radial immunodiffusion assay for plasma kininogen (kindly performed by Dr. Jocelyn Spragg, Boston, Mass.) revealed no detectable kininogen. Further, the radioimmunoassay for bradykinin was employed as an assay for kininogen by omitting the precipitation step usually used to separate plasma proteins from bradykinin. Essentially no detectable kinin-containing protein was found.

Plasminogen proactivator deficiency. Williams trait plasma generated essentially no fibrinolytic activity after kaolin activation, suggesting that it might be deficient in plasminogen proactivator. Since a direct assay of this factor in whole plasma is not yet available, we attempted to isolate plasminogen proactivator from Williams trait plasma and compare its yield with that obtained from normal plasma. $2.5 \mathrm{ml}$ of normal plasma or Williams trait plasma were dialyzed against $0.003 \mathrm{M}$ phosphate buffer, $\mathrm{pH} 8.0$, and fractionated simultaneously on $2 \times 10 \mathrm{~cm}$ columns of QAE Sephadex equilibrated with the same buffer. Each effluent was concentrated to $2 \mathrm{ml}$ and assayed for each Hageman factor substrate. The normal effluent and Williams trait effluent had the same PTA activity, as assessed by correction of the PTT of PTA-deficient plasma. Incubation of Hageman factor fragments with each effluent and incubation of the mixture with heat-inactivated plasma revealed that the Williams trait plasma had $45 \%$ of the prekallikrein content of the normal effluent. However, when each effluent was incubated with Hageman factor fragments and then plasminogen to assay for plasminogen proactivator (Fig. 4), the Williams trait effluent generated $4 \mu \mathrm{g}$ plasmin $/ \mathrm{ml}$ (the center well), while the normal plasma effluent generated $20 \mu \mathrm{g}$ plas-

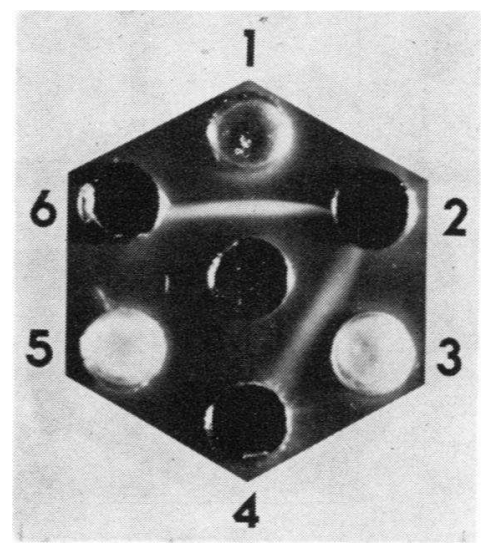

FIGURE 3 Ouchterlony analysis of Williams trait plasma with antibody to low molecular weight kininogen. Sheep anti-kininogen is in the center well. Well 1 contains normal plasma, well 3 contains a $1: 4$ dilution of normal plasma, and well 5 contains Williams trait plasma. Wells 2,4 , and 6 are empty. 


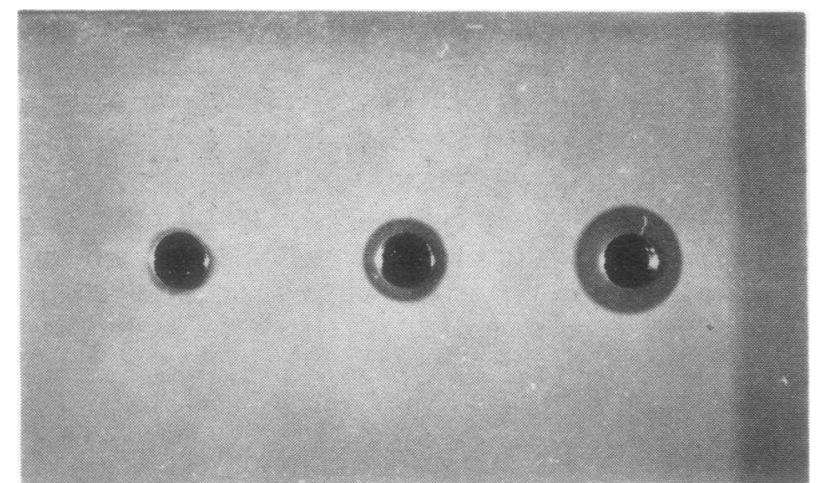

Figure 4 Fibrin plate assay of plasminogen proactivator isolated from equal volumes of normal plasma and Williams trait plasma. The left well contains plasminogen incubated with Hageman factor fragments and buffer, the center well contains plasminogen incubated with Hageman factor fragments plus plasminogen proactivator obtained from Williams trait plasma, and the right well contains plasminogen incubated with Hageman factor fragments plus plasminogen proactivator obtained from normal plasma.

$\mathrm{min} / \mathrm{ml}$. The plasminogen control on the left contained less than $1.0 \mu \mathrm{g}$ plasmin $/ \mathrm{ml}$. Thus the recovery of plasminogen proactivator from the Williams trait effluent was $20 \%$ of normal.
Correction of the abnormalities in Williams trait plasma. To identify the factor(s) that would correct the coagulation, fibrinolytic, kinin-generating, and prekallikrein activation defects of Williams trait plasma, normal plasma was fractionated on QAE Sephadex. 2 liters of plasma, dialyzed against $0.003 \mathrm{M}$ phosphate buffer, $\mathrm{pH} 8.0$, were applied to a $10 \times 100 \mathrm{~cm}$ column of QAE Sephadex equilibrated with the same buffer. The column was washed with 30 liters of the starting buffer, before stepwise elution with 30 liters of starting buffer containing $0.06 \mathrm{M} \mathrm{NaCl}, 0.12 \mathrm{M} \mathrm{NaCl}, 0.20 \mathrm{M}$ $\mathrm{NaCl}$, and $0.35 \mathrm{M} \mathrm{NaCl}$. As shown in Fig. 5, reconstitution with the initial effluent fraction, known to contain a mixture of the Hageman factor substrates, yielded a partial correction of the coagulation and fibrinolytic defects in Williams trait plasma. When a concentrate of this fraction was added back to equal volumes of Williams trait plasma, no correction of the abnormality in bradykinin generation was observed. This concentrate contained no functional or antigenic kininogen. The ability of this mixture to correct the abnormality in prekallikrein activation could not be determined satisfactorily by esterase assay because of the presence of active kallikrein. When the column was then sequentially eluted with buffers of increasing ionic strength, the $0.20 \mathrm{M}$ fraction contained a small amount of cor-

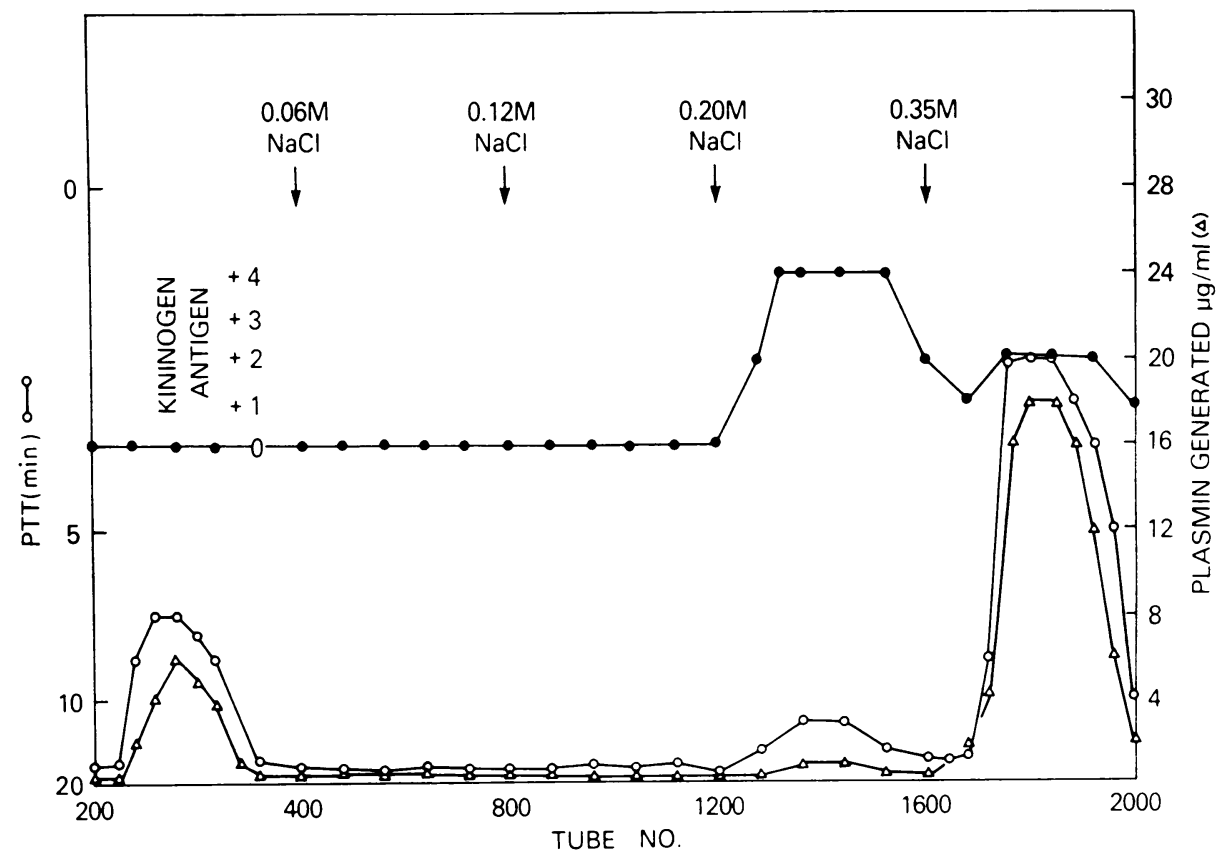

FigURE 5 QAE Sephadex chromatography of $2,000 \mathrm{ml}$ of normal plasma. After the effluent was obtained the column was washed with buffers of increasing $\mathrm{NaCl}$ concentration, as indicated. The column fractions were then assayed for kininogen antigen by counterimmunoelectrophoresis and for their ability to correct the coagulation and fibrinolytic defects of Williams trait plasma. 
rective activity while the major fraction that corrected the coagulation and fibrinolytic abnormalities in Williams trait plasma was found with the $0.35 \mathrm{M} \mathrm{NaCl}$ buffer. When these fractions were assayed for kininogen antigen, a major peak was observed in the fractions eluting with $0.20 \mathrm{M} \mathrm{NaCl}$ and a minor peak was observed in the fractions eluting with $0.35 \mathrm{M} \mathrm{NaCl}$. Assay of these fractions for functional kininogen with either trypsin or kallikrein revealed a correlation of the peaks of bradykinin generated with the assay for kininogen antigen. When the $0.35 \mathrm{M} \mathrm{NaCl}$ peak was concentrated to $500 \mathrm{ml}$ and an aliquot added to an equal volume of Williams trait plasma, incubation with kaolin for $2 \mathrm{~min}$ yielded $40 \%$ of the bradykinin released from a $1: 1$ dilution of normal plasma. Thus this fraction not only supplied a kininogen substrate but also corrected the abnormality in prekallikrein activation.

To distinguish further the various peaks that corrected the abnormalities in Williams trait plasma, the initial effluent was fractionated on SP-Sephadex, as previously described (5), to resolve the Hageman factor substrates. Direct assay of this column did not yield a peak that corrected the abnormalities in Williams trait plasma. However, when the column fractions were concentrated, partial correction of both the coagulation and fibrinolytic defects was obtained with a mixture containing prekallikrein and plasminogen proactivator but not with pre-PTA. This concentrate was then fractionated by gel filtration with Sephadex G 150 and the fractions were assayed for their ability to correct the coagulation and fibrinolytic defects in Williams trait plasma. As shown in Fig. 6, fractions containing plasminogen proactivator partially corrected each defect. Again, no correction of kaolin-dependent kinin generation was observed. When tubes $105-115$, containing the plasminogen proactivator peak, were concentrated and reassayed, about $10 \%$ plasminogen activator was present. Incubation of this concentrate with $10^{-3} \mathrm{M}$ diisopropylfluorophosphate (DFP) for $2 \mathrm{~h}$ at $37^{\circ} \mathrm{C}$, followed by extensive dialysis, destroyed its ability to correct Williams trait plasma. Thus the residual plasminogen proactivator, unaffected by this treatment, had no activity. However, the $0.35 \mathrm{M} \mathrm{NaCl}$ eluate from QAE Sephadex could correct all the abnormalities in Williams trait plasma. When this fraction was concentrated, dialyzed against $0.03 \mathrm{M}$ sodium acetate buffer. $\mathrm{pH}$ 5.6, and fractionated on SP-Sephadex equilibrated with the same buffer (Fig. 7), a small corrective peak appeared in the effluent coincident with a peak of protein, as assessed by OD $280 \mathrm{~nm}$, that contained a considerable quantity of kininogen antigen. After application of a gradient to $0.4 \mathrm{M} \mathrm{NaCl}$, a major peak was obtained that corrected the coagulation and fibrinolytic defects of Williams trait plasma superimposed upon the


Figure 6 Sephadex G 150 gel filtration of the mixture of prekallikrein and plasminogen proactivator derived from the QAE Sephadex effluent (Fig. 5). Below is shown the ability of these fractions to correct the coagulation and fibrinolytic abnormalities of Williams trait plasma.

elution of a second peak of antigenic kininogen. When tubes $675-900$ were concentrated to $20 \mathrm{ml}$, this fraction also corrected the prekallikrein activating and kininforming defects.

To determine the amount of kininogen necessary to correct the abnormality in prekallikrein activation, the $\mathrm{SP}$ concentrate was first assayed for its ability to correct quantitatively the coagulation defect in Williams trait plasma compared to normal plasma. The SP concentrate contained $28 \%$ Williams factor. Multiple dilutions of this factor were then prepared and equal volumes of each dilution were added to Williams trait plasma and assayed for kaolin-activated arginine esterase activity. A dose-dependent correction of the abnormality in prekallikrein activation was observed and maximal correction was obtained at $3.5 \%$ of normal plasma concentration (Fig. 8). Addition of this fraction to Williams trait plasma completely corrected the 


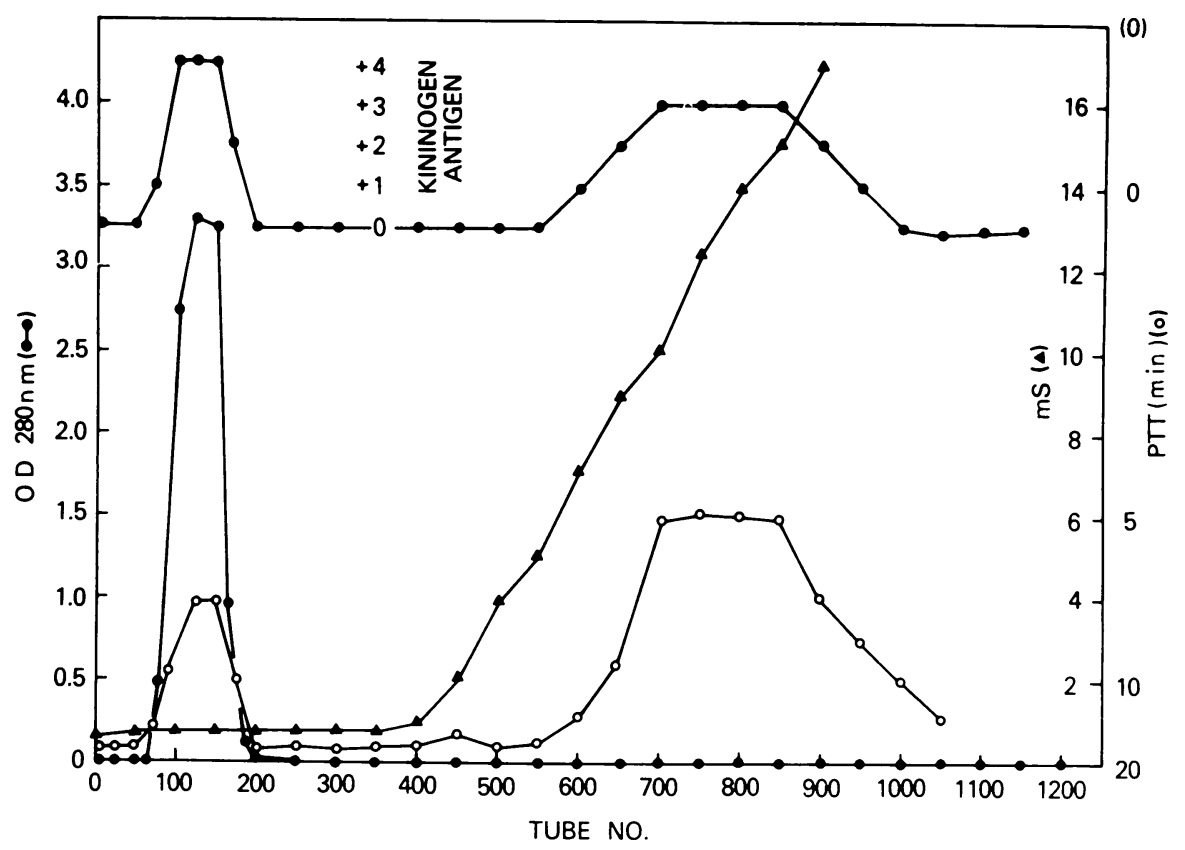

FIGURE 7 SP Sephadex chromatography of the $0.35 \mathrm{M} \mathrm{NaCl}$ fraction obtained from QAE Sephadex (Fig. 5). After the effluent was obtained, a linear salt gradient was applied, shown by the conductivity in millisiemens $(\mathrm{mS})$. The column fractions were assayed for kininogen antigen by counterimmunoelectrophoresis and for their ability to correct the coagulation defect in Williams trait plasma.

ability of kaolin to generate bradykinin as determined by bioassay.

This concentrate was next fractionated by gel filtration on a column of Sephadex G 150 calibrated with proteins of known molecular weight (6). As shown in Fig. 9, corrective peaks were obtained at mol wt 175,000 and 80.000 , each associated with a peak of kininogen

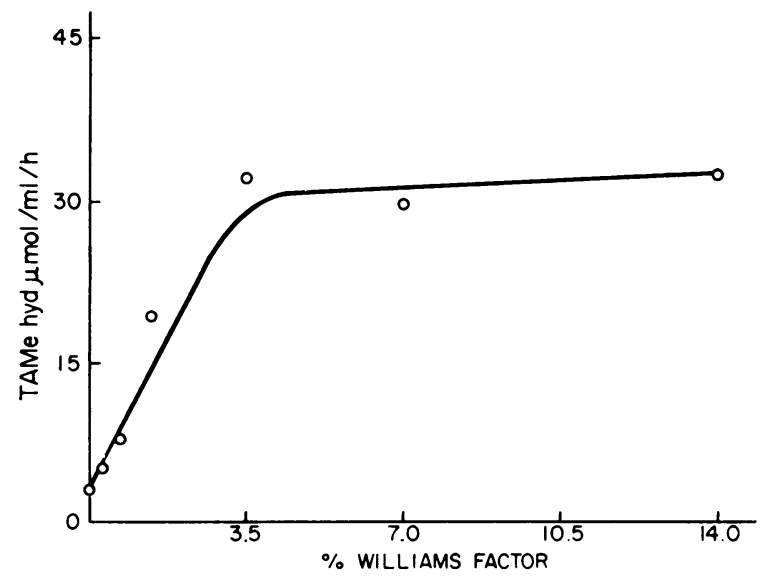

FIgURE 8 Dose-response of the quantity of Williams trait factor (expressed as a percent of normal plasma) required to correct the defect in prekallikrein activation, as assessed by the TAMe esterase assay. antigen. Thus it appeared that certain fractions of kininogen, containing a high molecular weight form as well as a low molecular weight form, could correct the coagulation and fibrinolytic abnormalities in Williams trait plasma. Nevertheless the bulk of the plasma kininogen of mol wt 80,000 present in the $0.20 \mathrm{M}$ fraction from QAE Sephadex (Fig. 6) and the effluent from SP-Sephadex (Fig. 7) failed to correct these abnormalities.

When highly purified kininogen was prepared as described in the Methods section, by DEAE cellulose batch adsorption, an antikininogen immunoadsorbent, chromatography on DEAE cellulose, and gel filtration on BioGel A $0.5 \mathrm{~m}$, kininogens could be further resolved by charge and size. Kininogen corresponding to the $0.20 \mathrm{M}$ eluate from QAE Sephadex was resolved on DEAE cellulose into three peaks, designated B1-3. The kininogen present in the $0.35 \mathrm{M} \mathrm{NaCl}$ eluate from QAE Sephadex was found as a separate peak on DEAE cellulose designated B4. As shown in Table V, the B1, B2, and $\mathrm{B} 3$ fractions were predominantly kininogens of low molecular weight, although fraction B3 $\beta$ was 150,000 daltons; these fractions did not correct Williams trait deficiency. The corrective factor was found associated only with the B4 fractions, regardless of their molecular weight. The most effective fraction, on a weight basis. was B4- $\gamma$. Removal of all of the bradykinin from B4- $\gamma$ 


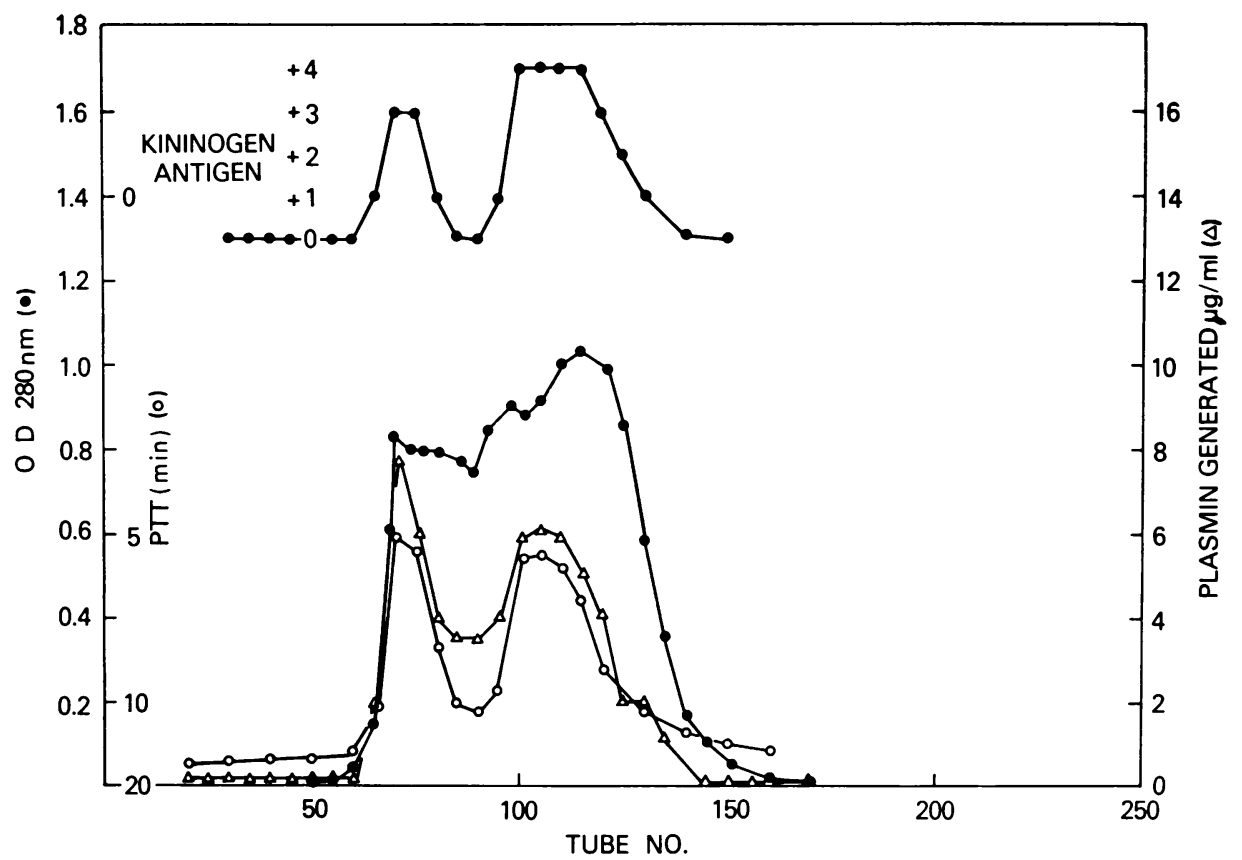

Figure 9 Sephadex G 150 gel filtration of the major peak of corrective activity eluted from SP Sephadex (Fig. 7). The column fractions were assayed for kininogen antigen by counterimmunoelectrophoresis and for their ability to correct the coagulation and fibrinolytic abnormalities in Williams trait plasma.

kininogen by digestion with kallikrein did not diminish its ability to correct the abnormalities in Williams trait plasma. When fraction $\mathrm{B} 4-\gamma$ was assessed by alkaline

TABLE V

Correction of the Coagulation, Fibrinolytic, and KininGenerating Defects in Williams Trait Plasma by Kininogens Isolated with an Antikininogen Immunoadsorbent, DEAE Cellulose Chromatography, and Gel Filtration

\begin{tabular}{cccc}
\hline \multirow{2}{*}{$\begin{array}{c}\text { DEAE } \\
\text { cellulose } \\
\text { kininogen } \\
\text { peaks }\end{array}$} & $\alpha(80,000)$ & $\beta(150,000)$ & $\gamma(225,000)$ \\
\cline { 2 - 4 } & \multicolumn{3}{c}{ \% total kininogen $\ddagger$} \\
B1 & $2.9(-)$ & $0.2(-)$ & 0 \\
B2 & $35.3(-)$ & $1.5(-)$ & 0 \\
B3 & $20.0(-)$ & $19.1(-)$ & 0 \\
B4 & $0.9(+)$ & $52.3(+)$ & $7.8(+)$ \\
\hline
\end{tabular}

* A crude kininogen fraction obtained from DEAE cellulose was passed over an antikininogen immunoadsorbent. Kininogen was eluted and recycled on DEAE cellulose to yield fractions B1-4. Each fraction was then passed over Bio-Gel A $0.5 \mathrm{~m}$ and the peaks obtained were designated $\alpha, \beta$, or $\gamma$ by molecular weight.

‡ The ability of each kininogen to correct Williams trait plasma was tested at a concentration of $150 \mu \mathrm{g} / \mathrm{ml}$. The results are indicated as positive $(+)$ or negative $(-)$. disc gel electrophoresis (Fig. 10), a single major band was seen. When a replicate unstained disc gel was sliced and each slice eluted and assayed, kininogen antigen was located at the same position as the protein band, and these same fractions corrected the coagulation defect in Williams trait plasma (Fig. 10).

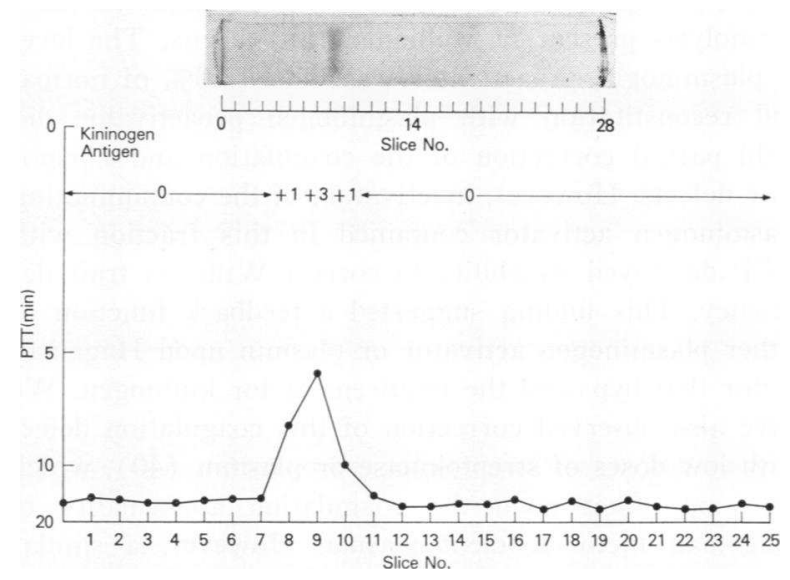

FIGURE 10 Alkaline disc gel electrophoresis at $\mathrm{pH} 9.3$ of $30 \mu \mathrm{g}$ of high molecular weight kininogen (B4- $\gamma$ ) obtained from Bio-Gel $0.5 \mathrm{~m}$. A replicate disc gel was sliced and eluted, and this eluate was assayed for kininogen antigen by counterimmunoelectrophoresis and for its ability to correct the coagulation defect of Williams trait plasma. 


\section{DISCUSSION}

The plasma obtained from Ms. Williams, like Hageman and Fletcher trait plasmas, possesses profound in vitro abnormalities of surface-activated coagulation, fibrinolysis, and kinin generation, yet the patient has no clinical evidence of bleeding. Although these abnormalities might suggest Hageman factor deficiency, Williams trait plasma has normal Hageman factor content and function, as assessed by a coagulant assay with Hageman factor-deficient plasma as the substrate. Fletcher factor (prekallikrein) deficiency also has abnormalities of each Hageman factor-dependent pathway; it generates no kinin because it lacks the Hageman factor substrate, prekallikrein, and has an abnormal rate of activation of Hageman factor attributable to a feedback effect of kallikrein upon Hageman factor (1113). Thus, in Fletcher trait plasma, the kaolin-activable coagulation and fibrinolysis are prolonged, but gradually correct as the incubation time with kaolin is increased $(10,11)$. However, the coagulation defect in Williams trait plasma is not corrected by prolonged incubation with kaolin. By direct coagulant assay, immunochemical determination and kinin-formation (in the presence of added kininogen) Williams trait plasma has $45 \%$ prekallikrein, a level 5 to 10 times that required for the kallikrein feedback to function (9). Addition of aliquots of either Hageman or Fletcher trait plasmas to Williams trait plasma completely corrects its prolonged PTT and its defect in kaolin-activated euglobulin lysis, indicating that Williams trait plasma lacks a factor present in these other deficient plasmas.

An abnormality in plasminogen proactivator was suspected because of the profound defect in kaolin-activable fibrinolysis present in Williams trait plasma. The level of plasminogen proactivator was indeed $20 \%$ of normal and reconstitution with plasminogen proactivator did yield partial correction of the coagulation and fibrinolytic defects. However, inactivation of the contaminating plasminogen activator contained in this fraction with DFP destroyed its ability to correct Williams trait deficiency. This finding suggested a feedback function of either plasminogen activator or plasmin upon Hageman factor that bypassed the requirement for kininogen. We have also observed correction of this coagulation defect with low doses of streptokinase or plasmin (40), which have no effect upon the coagulation abnormality of Hageman factor-deficient plasma. However, a similar correction of the coagulation abnormality of Fletcher trait plasma was observed with either streptokinase or plasmin. Thus, the partial correction of coagulation observed in the QAE Sephadex effluent (Fig. 5) and its subsequent fractionation (Fig. 6) is probably due to a feedback effect of plasmin upon Hageman factor demonstrable in those plasmas possessing an abnormal rate of Hageman factor activation. Evidence of such a feedback effect of plasmin upon Hageman factor was originally given by Kaplan and Austen (41), based upon in vitro studies of Hageman factor activation and fragmentation.

The major defect present in Williams trait plasma, therefore, does not appear to be secondary to plasminogen proactivator deficiency. This plasma contains no detectable kininogen and fractions containing certain forms of kininogen completely correct the kinin-generating defect. Yet Williams trait plasma does not activate its prekallikrein as assessed by an arginine esterase assay; thus, insufficient prekallikrein is activated for the kallikrein feedback to function. Reconstitution with the kininogen-containing fractions corrects this abnormality in prekallikrein activation, as well as the coagulation and fibrinolytic defects, suggesting an effect upon Hageman factor, the one protein common to each of these pathways. Furthermore, since kininogen is required for the formation of plasmin and kallikrein, this protein is a prerequisite for the known feedback effects of these enzymes upon Hageman factor. It is of particular interest that the fibrinolytic defect is corrected by kininogen in the absence of additional plasminogen proactivator. It may be that $20 \%$ of normal plasminogen proactivator is sufficient if the initiating steps in Hageman factor-dependent fibrinolysis are normal.

Recently three other patients have been described who possess abnormalities similar to those present in Williams trait deficiency. In the first, termed Fitzgerald trait (42), the missing factor was distinguished from Hageman factor and Fletcher factor. However, the corrective protein was not identified. In the second, Flaujeac deficiency (43), the functional abnormalities have been ascribed to absence of high molecular weight kininogen. Both Flaujeac and Fitzgerald trait plasmas also possess an abnormality in the formation of the permeability factor $(\mathrm{PF} / \mathrm{dil})$. Since $\mathrm{PF} / \mathrm{dil}$ has been shown to be identical to actiz'atcd Hageman factor $(5,18,44)$, these plasmas appear to possess a defect in Hageman factor activation that is kininogen dependent. In the third patient (45), who also has a deficiency of kininogen, genetic studies indicate an autosomal recessive pattern of inheritance. Flaujeac trait plasma has normal prekallikrein, Fitzgerald trait plasma has $10-15 \%$ prekallikrein, while Williams trait plasma has $45 \%$ prekallikrein and $20 \%$ plasminogen proactivator. The association of diminished levels of three separate protein abnormalities in Williams trait plasma could be explained by several hypotheses. The functional relationship of these proteins suggests a genetic linkage, thus the diminished levels may reflect a synthetic defect. Combined deficiencies of functionally related proteins in the 
coagulation pathway have been previously documented, such as Factors VII and IX deficiency (46) and Factor $\mathrm{V}$ and VIII deficiency (47). Alternatively, functional absence of an inhibitor might lead to accelerated catabolism of these proteins, as observed with $\mathrm{C} 3 \mathrm{~b}$ inactivator deficiency (48). Further studies are required to distinguish these possibilities.

Finally, our results are also relevant to considerations of the number of kininogens that circulate in plasma. Although it is clear from the studies of Spragg and Austen that the majority of plasma kininogen is of low molecular weight (49), this does not appear to be the sole form of native human kininogen. Previous authors have described a human high molecular weight kininogen that possesses different kinetic properties when activated by kallikrein $(15,20,50,51)$. It is clear from our studies that such a high molecular weight kininogen can be separated from low molecular weight kininogen and this kininogen has a special function in the early steps of the Hageman factor-dependent pathways. The bulk of plasma low molecular weight kininogen is found in our $0.20 \mathrm{M}$ fraction from QAE Sephadex and in the effluent from SP Sephadex, and possesses little ability to correct Williams trait deficiency, although it is functional as a kallikrein substrate. However, we have also found a low molecular weight kininogen-containing fraction (Fig. 9) that corrects Williams trait deficiency, indicating that it contains the same activity associated with the high molecular weight form. When kininogens were isolated by an alternative procedure (Table IV), only the B4 kininogens, comprising $22 \%$ of total kininogen, corrected Williams trait deficiency. Analysis of this fraction by gel filtration indicates that each of the molecular weight subfractions corrects Williams trait plasma. These are the same kininogen fractions found to have the highest affinity for plasma kallikrein and the greatest rate of cleavage by plasma kallikrein, regardless of size $(21,22)$. When we previously fractionated $50 \mathrm{ml}$ of Hageman factordeficient plasma to isolate the Williams factor, all of the corrective activity was found at a mol wt of 175,000 , although its identity was not known (52). It is therefore possible that lower molecular weight forms of kininogen that correct Williams trait deficiency are derived from the heavier fraction, while $\mathrm{B} 3-\beta$, a heavier fraction that does not correct Williams trait deficiency, is a dimer of a low molecular weight kininogen. Alternatively, the large volumes of plasma utilized on the present study may have allowed identification of kininogen heterogeneity that was not previously appreciated.

\section{ACKNOWLEDGMENTS}

This work was supported in part by grant HL 16642 and grant HL 14479 from the National Institutes of Health.

\section{REFERENCES}

1. Ratnoff, O. D., E. W. Davie, and D. L. Mallett. 1961. Studies on the action of Hageman factor: evidence that activated Hageman factor in turn activates plasma thromboplastin antecedent. J. Clin. Inz'est. 40: 803-819.

2. Margolis, J. 1958. Activation of plasma by contact with glass: Evidence for a common reaction which releases plasma kinin and initiates coagulation. J. Physiol. (Lond.). 144 : 1-22.

3. Iatridis, S. G., and J. H. Ferguson. 1962. Active Hageman factor: A plasma lysokinase of the human fibrinolytic system. J. Clin. Inv'est. 41 : 1277-1287.

4. Niewiarowski, S., and O. Prou-Wartelle. 1959. Role du facteur contact (Facteur Hageman) dans la fibrinolyse. Thromb. Diath. Haemorrh. 3: 593-603.

5. Kaplan, A. P., and K. F. Austen. 1970. A prealbumin activator of prekallikrein. J. Immunol. 105: 802-811.

6. Kaplan, A. P., and K. F. Austen. 1972. The fibrinolytic pathway of human plasma. Isolation and characterization of the plasminogen proactivator. J. Exp. Med. 136: 1378-1393.

7. Ratnoff, O. D., and J. E. Colopy. 1955. A familial hemorrhagic trait associated with a deficiency of a clot-promoting fraction of plasma. J. Clin. Invest. 34 : 602-613.

8. Rosenthal, R. L., O. H. Dreskin, and N. Rosenthal. 1953. New hemophilia-like disease caused by a deficiency of a third plasma thromboplastin factor. Proc. Soc. Exp. Biol. Med. 82 : 171-174.

9. Wuepper, K. D. 1972. Biochemistry and biology of components of the plasma kinin-forming system. In Inflammation: Mechanisms and Control. I. H. Lepow and P. A. Ward, editors. Academic Press, Inc., New York. 93-117.

10. Wuepper, K. D. 1973. Prekallikrein deficiency in man. J. Exp. Med. 138: 1345-1355.

11. Weiss, A. S., J. I. Gallin, and A. P. Kaplan. 1974. Fletcher factor deficiency. A diminished rate of Hageman factor activation caused by absence of prekallikrein with abnormalities of coagulation, fibrinolysis, chemotactic activity, and kinin generation. J. Clin. Invest. 53: 622-633.

12. Bagdasarian, A., B. Lahiri, and R. W. Colman. 1973. Origin of the high molecular weight activation of prekallikrein. J. Biol. Chem. 248: 7742-7747.

13. Cochrane, C. G., S. D. Revak, and K. D. Wuepper. 1973. Activation of Hageman factor in solid and fluid phases. A critical role of kallikrein. J. Exp. Med. 138: 1564-1583.

14. Bagdasarian, A., B. Lahiri, R. C. Talamo, P. Wong, and R. W. Colman. 1974. Immunochemical studies of plasma kallikrein. J. Clin. Invest. 54: 1444-1454.

15. Pierce, J. V., and M. E. Webster. 1966. The purification and some properties of two different kallidinogens from human plasma. Hypotensive Peptides Proc. Int. Sl'mp. $1: 130-138$.

16. Pierce, J. V. 1968. Structural features of plasma kinins and kininogens. Fed. Proc. $27: 52-57$.

17. Weber, K., and M. Osborn. 1969. The reliability of molecular weight determinations by dodecyl sulfatepolyacrylamide gel electrophoresis. J. Biol. Chem. 244 : 4406-4412.

18. Bagdasarian, A., R. C. Talamo, and R. W. Colman. 1973. Isolation of high molecular weight activators of human plasma prekallikrein. J. Biol. Chem. 248: 34563463. 
19. Kaplan, A. P., J. Spragg, and K. F. Austen. 1971. The bradykinin-forming system of man. In Biochemistry of the Acute Allergic Reactions. Second international symposium. K. Frank Austen and E. L. Becker, editors. Blackwell Scientific Publications Ltd., Oxford, England. 279-298.

20. Deutsch, D. G., and E. T. Mertz. 1970. Plasminogen: purification from human plasma by affinity chromatography. Science (Wash. D. C.). 170: 1095-1096.

21. Guimaraes, J. A., R. Chenlu, M. E. Webster, and J. V. Pierce. 1974. Multiple forms of human plasma kininogen. Fed. Proc. 33: 641. (Abstr.)

22. Pierce, J. V., and J. A. Guimaraes. 1975. Further characterization of highly purified human plasma kininogens. In The Kallikrein System in Health and Disease. Fogarty International Center Proceedings No. 27. U. S. Government Printing Office, Washington, D. C. In press.

23. Axén, R., J. Porath, and S. Ernback. 1967. Chemical coupling of peptides and proteins to polysaccharides by cyanogen halides. Nature (Lond.). 214: 1302-1304.

24. Mancini, G., A. O. Carbonaro, and J. F. Heremans. 1965. Immunochemical quantitation of antigens by single radial immunodiffusion. Immunochemistry. 2: 235-254.

25. Colman, R. W., L. Mattler, and S. Sherry. 1969. Studies on the prekallikrein (kallikreinogen)-kallikrein enzyme system of human plasma. I. Isolation and purification of plasma kallikrein. J. Clin. Iniest. 48: $11-22$.

26. Gigli, I., J. W. Mason, R. W. Colman, and K. F. Austen. 1970. Interactions of plasma kallikrein with $\mathrm{C}_{1}^{-}$inhibitor. J. Immunol. 104: 574-581.

27. Proctor, R. R., and S. I. Rappoport. 1961. The partial thromboplastin time with kaolin: a simple screening test for first stage plasma clotting deficiencies. Am. J. Clin. Pathol. 35 : 212-219.

28. Owren, P. A., and K. Aas. 1951. The control of dicumarol therapy and the quantitative determination of prothrombin and proconvertin. Scand. J. Clin. Lab. Iniest. 3: 201-208.

29. Lewis, M. L., and A. G. Ware. 1953. A one-stage method of determination of accelerator globulin. Proc. Soc. Exp. Biol. Mcd. 84: 640-643.

30. Pechet, L. 1964. Determination of Factor VII (proconvertin). In Blood Coagulation, Hemorrhage and Thrombosis. L. M. Tocantins and L. A. Kazal, editors. Grune and Stratton, New York. 213-218.

31. Bachman, F., R. Duckert, and R. Koller. 1958. The Stuart-Prower factor assay and its clinical significance. Thromb. Diath. Hacmorrh. 2: 24-38.

32. Clauss, A. 1957. Gerinnungsphysiologische Schnellmethode zur Bestimmung des Fibrinogens. Acta Ilacmatol. (Basel). 17 : 237-246.

33. Garvey, M. B., and J. M. Block. 1972. The detection of fibrinogen/fibrin degradation products by means of a new antibody-coated latex particle. J. Clin. Pathol. 25: 680-682.

34. Alkjaersig, N., A. P. Fletcher, and S. Sherry. 1959. $\epsilon$-aminocaproic acid: an inhibitor of plasminogen activation. J. Biol. Chcm. 234: 832-837.

35. Siegelman, A. M., A. S. Carlson, and T. Robertson. 1962. Investigation of serum trypsin and related substances. I. The quantitative demonstration of trypsinlike activity in human blood serum by a micromethod. Arch. Biochem. Biophys. 97: 159-163.

36. Colman, R. W., J. W. Mason, and S. Sherry. 1969. The kallikreinogen-kallikrein enzyme system of human plasma. Assays of components and observations in disease states. Ann. Intern. Med. 71: 763-773.

37. Schreiber, A. D., A. P. Kaplan, and K. F. Austen. 1973. Plasma inhibitors of the components of the fibrinolytic pathway in man. J. Clin. Inc'est. 52: 1394-1401.

38. Talamo, R. C., E. Haber, and K. F. Austen. 1969. A radioimmunoassay for bradykinin in plasma and synovial fluid. J. Lab. Clin. Med. 74: 816-827.

39. Ouchterlony, Ö. 1953. Antigen-antibody reactions in gels. IV. Type of reactions in coordinated systems of diffusion. Acta Pathol. Microbiol. Scand. 32: 231-240.

40. Kaplan, A. P., A. Bagdasarian, and R. W. Colman. 1975. Williams trait deficiency. Abnormalities of coagulation, fibrinolysis, and kinin generation and their relationship to plasminogen proactivator. Clin. Res. 23: 403A. (Abstr.)

41. Kaplan, A. P., and K. F. Austen. 1971. A prealbumin activator of prekallikrein. II. Derivation of activators of prekallikrein from active Hageman factor by digestion with plasmin. J. Exp. Med. 133: 696-712.

42. Saito, H., O. D. Ratnoff, K. Waldmann, and J. P. Abraham. 1975. Fitzgerald trait. Deficiency of a hitherto unrecognized agent, Fitzgerald factor, participating in surface-mediated reactions of clotting, fibrinolysis, generation of kinins, and the property of diluted plasma enhancing vascular permeability $(\mathrm{PF} / \mathrm{dil})$. J. Clin. Inz'est. 55: 1082-1089.

43. Wuepper, K. D., D. R. Miller, and M. J. Lacombe. 1975. Flaujeac trait: deficiency of kininogen in man. Fed. Proc. $34:$ 859. (Abstr.)

44. Johnston, A. R., C. G. Cochrane, and S. D. Revak. 1974. The relationship between $\mathrm{PF} / \mathrm{dil}$ and activated human Hageman factor. J. Immunol. 113: 103-109.

45. Donaldson, V. H., H. I. Glueck, and M. A. Miller. 1975. Kininogen deficiency and defective surface activation of blood coagulation and fibrinolysis in a kindred with Fitzgerald trait. Fifth Congress of the International Society of Thrombosis and Hemostasis. In press. (Abstr.)

46. Bell, W. N., and H. G. Alton. 1955. Christmas disease associated with Factor VII deficiency. Case report with family survey. Br. Med. J. 1: 330-331.

47. Iverson, T., and P. Bastrup-Madsen. 1956. Congenital familial deficiency of Factor $\mathrm{V}$ (parahemophilia) combined with deficiency of anti-hemophilic globulin. $\mathrm{Br}$. J. Hematol. 2 : 265-275.

48. Ziegler, J. B., C. A. Alper, F. S. Rosen, P. J. Luckmann, and L. Sherington. 1975. Restoration by purified $\mathrm{C} 3 \mathrm{~b}$ inactivator of complement-mediated function in vivo in a patient with $\mathrm{C} 3 \mathrm{~b}$ inactivator deficiency. J. Clin. Ini'st. 55: 668-672.

49. Spragg, J., and K. F. Austen. 1971. The preparation of human kininogen. II. Further characterization of purified human kininogen. J. Immunol. 107: 1512-1519.

50. Jacobsen, S., and M. Kriz. 1967. Some data on two purified kininogens from human plasma. Br.J. Pharmacol. Chemother. 29: 25-36

51. Habal, F. M., H. Z. Movat, and C. E. Burrowes. 1974. Isolation of two functionally different kininogens from human plasma. Separation from proteinase inhibitors and interaction with plasma kallikrein. Biochem. Pharmacol. 23: 2291-2302.

52. Colman, R. W., A. Bagdasarian, R. C. Talamo, M. Seavey, C. F. Scott, and A. P. Kaplan. 1975. Williams trait. Combined deficiency of plasma plasminogen proactivator, kininogen and a new procoagulant factor. Fed. Proc. 34: 859. (Abstr.) 